\title{
Refrigerated and frozen storage impact aronia berry quality
}

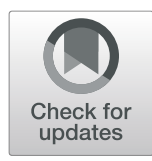

\author{
Erica S. King ${ }^{1}$, Andrea Noll', Susan Glenn ${ }^{2}$ and Bradley W. Bolling ${ }^{1 *}$ (i)
}

\begin{abstract}
Postharvest storage of many freshly picked berries affects polyphenol and sugar content. However, little is known about the impact of refrigerated and frozen storage on aronia berry composition. Therefore, the objective of this study was to characterize how storage at $4 \pm 2{ }^{\circ} \mathrm{C}$ and $-20 \pm 2{ }^{\circ} \mathrm{C}$, and temperature cycles affect aronia berry polyphenols, total solid content, pH, titratable acidity, polyphenol oxidase (PPO) activity, sugar content, acid content, color, and cell structure. Refrigerated storage reduced proanthocyanidins (21\%), anthocyanins (36\%), and total phenols (21\%) after 12 weeks. Frozen storage increased polyphenols in the first 6 mo. of frozen storage but then decreased polyphenols at mo. 8 to levels similar to initial values. Frozen temperature cycling reduced anthocyanins $18 \%$ but did not affect total phenols or proanthocyanidins. Scanning electron microscopy analysis indicated temperature cycling induced cell damage, shrinking, and fusion. This disruption led to the release of anthocyanins inside the berry tissue. PPO activity did not significantly correlate with the decrease in polyphenol content during storage. ${ }^{\circ}$ Brix did not significantly change during refrigeration and frozen storage but did during the 12th temperature cycle. Aronia berries' pH and titratable acidity were affected more by refrigeration than frozen and temperature storage. The $\mathrm{pH}$ increased by $4 \%$ during refrigeration, and titratable acidity decreased by $17 \%$ at 12 weeks. In conclusion, refrigerated storage results in a modest reduction of aronia berry polyphenols, but absolute extractable polyphenols are stable for up to 8 months of frozen storage.
\end{abstract}

Keywords: Aronia berry, Polyphenols, Storage, Refrigeration, Sugars, Acids, Frozen

\section{Introduction}

Berries have polyphenols and nutrients that promote human health (Diaconeasa 2018). Unlike climacteric fruit, berries are non-climacteric and harvested at full maturity because they will not continue to ripen (Kahramanoglu 2017). However, because they are harvested fully ripened, fresh berries have short shelf lives because of high respiration rates, water loss, and susceptibility toward decay and damage. Thus, postharvest storage changes berry composition, including soluble solids, $\mathrm{pH}$, titratable acidity, polyphenol content, vitamins, and minerals (Kahramanoglu 2017). Therefore, it is essential to characterize and optimize the postharvest storage of berries to limit polyphenol and nutrient loss.

\footnotetext{
* Correspondence: bwbolling@wisc.edu

${ }^{1}$ Department of Food Science, University of Wisconsin-Madison, 1605 Linden Dr., Madison, WI 53706, USA

Full list of author information is available at the end of the article
}

Berries are preserved by refrigeration, freezing, drying, canning, or processing into jams, jellies, and juices. Berry polyphenols are sensitive to light, oxygen, increased $\mathrm{pH}$, and heat, so refrigeration and freezing are used for short and long-term storage (Diaconeasa 2018). Lowering the temperature reduces mold growth, respiration rate, pigment degradation, chemical changes in flavor, acid deterioration, sugar conversions, and enzymatic reactions with polyphenols and the cell structure (Yahia et al. 2017). Prior studies have illustrated how freezing impacts berry polyphenols over extended periods. The results from all the different studies indicate, the rates of change of polyphenols, nutrients, sugars, and acids during storage and temperature depends on the berry type, cultivar, and fruit maturity (Khattab et al. 2015; Rickman et al. 2007; Šamec \& Piljac-Žegarac 2014).

When fruit is stored in the freezer, most water becomes ice, reducing microbial, oxidation, and enzymatic

(c) The Author(s). 2022 Open Access This article is licensed under a Creative Commons Attribution 4.0 International License, which permits use, sharing, adaptation, distribution and reproduction in any medium or format, as long as you give appropriate credit to the original author(s) and the source, provide a link to the Creative Commons licence, and indicate if changes were made. The images or other third party material in this article are included in the article's Creative Commons licence, unless indicated otherwise in a credit line to the material. If material is not included in the article's Creative Commons licence and your intended use is not permitted by statutory regulation or exceeds the permitted use, you will need to obtain permission directly from the copyright holder. To view a copy of this licence, visit http://creativecommons.org/licenses/by/4.0/. 
reactions (Šamec \& Piljac-Žegarac 2014). Consequently, cell damage occurs from the ice-crystal formation during freezing, resulting in alterations of a fruit's structure and composition. Additionally, the fruit will go through temperature fluctuations due to storage (refrigeration temperature change), transportation, and consumer treatment, leading to temperature abuse that cause a reduction in nutrients and physical deterioration (Hajji et al. 2019).

Aronia berries contain significant amounts of anthocyanin, proanthocyanidin, phenolic acids and flavonol polyphenols. Anthocyanins are the predominant polyphenol in aronia berries and are mainly cyanidin glycosides. Taheri et al. (2013) reported the order of anthocyanin abundance as: cyanidin-3-O-galactoside > cyanidin-3- $O$-arabinoside > cyanidin-3- $O$-glucoside. The proanthocyanidins in aronia berries are mainly highly-polymerized B-type procyanidins (Taheri et al. 2013; Wu et al. 2004). The primary proanthocyanidins in aronia berries are polymers with degrees of polymerization $>10$ and contain $1-19 \%$ with degrees of polymerization < 10 (Taheri et al. 2013; Wu et al. 2004). Aronia flavonols are largely quercetin galactosides, glucosides, or rutinosides attached to the molecule, while its phenolic acids are primarily hydroxcinnamic acids (Taheri et al. 2013). The abundance of these polyphenols, particularly the anthocyanins, contribute to the potential health benefits of aronia berry consumption (King \& Bolling 2020; Valdez \& Bolling 2019).

Less is known about the impact of refrigerated and frozen storage on aronia berry quality. Prior studies reported how storage affects the phytochemicals in aronia berry juice, jam, and puree (Wilkes et al. 2014; Georgiev and Ludneva 2009; Yuan et al. 2018). Nevertheless, the stability of heat-treated and fresh fruit is not comparable due to the deactivation of enzymes in processed products (Piljac-Žegarac \& Šamec 2011). To our knowledge, there are currently no reports on how refrigerated and frozen storage affects aronia berry quality. Therefore, this study was created to increase our understanding of how aronia berries change in composition during longterm storage. This study evaluates the effects on aronia berries in different storage conditions (refrigeration $4 \pm$ $2{ }^{\circ} \mathrm{C}$, freezer $-20 \pm 2{ }^{\circ} \mathrm{C}$, and temperature cycles) by examining polyphenols, total solid content, $\mathrm{pH}$, titratable acidity, polyphenol oxidase (PPO), sugar content, acid content, color, and cell structure.

\section{Materials and methods Reagents}

(+)-Catechin hydrate (98\% purity) was from Cayman Chemical (Ann Arbor, MI, U.S.A.). 4- (Dimethylamino) cinnamaldehyde, TRIZMA buffer (primary Standard and Buffer, $\geq 99.9 \%$ ), TRIZMA hydrochloride (reagent grade, $\geq 99.0 \%$ ), catechol (99\% purity),calcium chloride dihydrate (ACS reagent grade, 99\% pure), sodium dibasic (ACS reagent grade), sodium phosphate monobasic (ACS reagent grade), Titron $\mathrm{x}-100$ (laboratory grade), Folin \& Ciocalteu's phenol reagent, formic acid (reagent grade $\geq 95 \%$ pure)), sodium bicarbonate (BioReagent), were from Sigma-Aldrich (St. Louis, MO, U.S.A). Acetone (HPLC grade), hydrochloric acid (ACS reagent grade), potassium acid phthalate, potassium chloride (ACS reagent grade) from Thermo Fisher Scientific (Waltham, MA, U.S.A). Ethanol (anhydrous, USP standard) was from Decon Labs (King of Prussia, PA, U.S.A.). Gallic acid monohydrate (ACS reagent grade) was from Acros Organic morris plains NJ, USA. Sodium Hydroxide $(1.0007 \mathrm{~N})$ was from La-Mar-Ka (Baton Rouge, LA. U.S.A). Ultrapure water was filtered at $>18.1 \mathrm{M} \Omega \mathrm{cm}$ using a Barnstead water filtration system (Thermo Fisher Scientific).

\section{Storage conditions}

For experiments evaluating storage on aronia berry quality, 'Viking' aronia berries were collected from 6 different plants in Madison, equivalent to week 4 of harvest, were analyzed as $n=4$ composite samples representing berries from 1 to 3 different plants each. For these experiments, $\sim 125 \mathrm{~g}$ of freshly harvested berries were sealed in a sealed plastic bag and subjected to different storage conditions. These included fresh berries (extracts and juices were prepared on the same day of harvest), refrigeration $\left(4 \pm 2{ }^{\circ} \mathrm{C}\right.$ for $2,4,6,8,10,12$ weeks $)$, freezer $\left(-20 \pm 2{ }^{\circ} \mathrm{C}\right.$ for $1,2,4,6,8 \mathrm{mo}$.), and temperature cycles. To minimize temperature change, the berries were stored in drawers during the refrigeration, freezer, and temperature cycles experiments.

\section{Frozen temperature cycling experiments}

Fresh aronia berries were placed in $125 \mathrm{~g}$ aliquots in sealed plastic bags and stored in a $-20 \pm 2{ }^{\circ} \mathrm{C}$ freezer drawer for 4 mo., using a frost-free freezer (Insignia 17.0 Cu. Ft. Frost-Free Upright Convertible Freezer/Refrigerator; Model: NS-UZ17WH0). The freezing point of aronia berry juice was determined to be $-2^{\circ} \mathrm{C}$ using The Advanced $^{\mathrm{Tm}}$ Osmometer Model 3250 (Thermo Fisher Scientific, Waltham, MA, U.S.A). Next, the frozen berries were subjected to temperature cycles making sure the temperature of berries did not rise above the freezing point of aronia berry juice. Each cycle started with berries at $-20 \pm 2{ }^{\circ} \mathrm{C}$, followed by placing the berries in open bags in a $60 \mathrm{~Hz}$ microwave on defrost setting for 5 $\mathrm{s}$. The bag of berries were taken out of the microwave shaken up and placed back in the microwave for $5 \mathrm{~s}$. Then, a temperature probe was used to measure the temperature of three different berries. Berries with temperatures -3 to $-2{ }^{\circ} \mathrm{C}$ were placed back in the freezer. 
However, if the berries were below $-3{ }^{\circ} \mathrm{C}$, they were microwaved for another 5 or $10 \mathrm{~s}$ until they reached -3 or $-2{ }^{\circ} \mathrm{C}$. Every other day, the procedure was repeated to ensure the aronia berries were frozen before warming them up again to $-2{ }^{\circ} \mathrm{C}$. Berries went through 24 temperature cycles, the composition of the aronia berry was evaluated every 6th temperature cycle. Experiments were repeated in 4 separate batches for each of the four conditions. After each temperature cycle was completed, the berries were analyzed for their polyphenol, sugar, acid, and PPO content. Additionally, they were lyophilized to examine the cell structure by microscopy and color change.

\section{SEM analysis}

Representative aronia samples were taken from each temperature cycle $(6,12,18$, and 24$)$ with additional control aronia samples that did not go through the temperature cycles. The samples were cut in half to show the cells and tissue structure under a scanning electron microscope (SEM). The fractions were placed in a freeze-dryer for $48 \mathrm{~h}$ to ensure no moisture was left in the aronia samples. Samples were mounted on a 12.7X11MM pin mount (Ted Pella Inc., Redding, CA, U.S.A) fracture side up and coated with platinum $10 \mathrm{um}$ thick, using a Prep-Leica ACE600 Deposition. The samples were with an SEM Zeiss GeminiSEM 450. Pictures were taken using the magnification of 50x. Two samples from control and each treatment were examined and used for results.

\section{Polyphenol content}

To extract polyphenols, aronia berries were placed under liquid nitrogen and immediately ground to a powder with a blender. The frozen berry powder $(100 \mathrm{mg})$ was placed into a $25 \mathrm{~mL}$ centrifuge tube with $10 \mathrm{~mL}$ of acetone: water (70:30) and extracted for $24 \mathrm{~h}$ on a test tube rocker at ambient conditions. The polyphenol profile aronia berries has been well established elsewhere (King \& Bolling 2020; Taheri et al. 2013). Spectrophotometric methods for analysis of anthocyanins, proanthocyanidins, and total phenols correlate with LC-MS and HPLC-DAD methods for quantitation of aronia phenolics (Taheri et al. 2013; Bolling et al. 2015). Thus, standardized spectrophotometric methods adapted for 96well microplates were used for aronia berry phenolic analysis. Extracts were centrifuged, and total phenols were assessed by the Folin-Ciocalteu assay as gallic acid equivalents (Singleton et al. 1999); anthocyanins by the $\mathrm{pH}$ differential method as cyanidin-3-glucoside equivalents (Lee et al. 2005); and proanthocyanidins by the 4dimethylaminocinnamaldehyde (DMAC) method as (+)-catechin equivalents (Prior et al. 2010).

\section{Acid and ${ }^{\circ}$ brix content}

Aronia berries ( $45 \mathrm{~g}$ ) were juiced using a hand press prior to the determination of $\mathrm{pH}$, titratable acidity, and ${ }^{\circ}$ Brix. Briefly, juice was centrifuged and $\mathrm{pH}$ determined with a Seven Compact pH/Ion meter S220 (Mettler Toledo, Columbus, OH, U.S.A.); titratable acidity by titration with potassium acid phthalate to pH 7.0 (Nielsen 2003); and ${ }^{\circ}$ Brix with an Abbe refractometer (Thermo-Spectronic, U.S.A).

\section{Polyphenol oxidase (PPO) activity}

The method for extraction and analysis of PPO activity was modified from Siddiq \& Dolan (2017). First, $15 \mathrm{~g}$ of aronia berries were submerged in liquid nitrogen and blended to a powder, from which $12.5 \mathrm{~g}$ was transferred to a $50 \mathrm{~mL}$ centrifuge tube. To lyse any intact cells, $25 \mathrm{~mL}$ of $0.1 \mathrm{M}$ pH 9.5 TRIZMA buffer and $0.5 \%$ of Triton $\mathrm{X}-100$ was added to the centrifuge tube, vortexed for $30 \mathrm{~s}$, and placed on a rocker for 10 min. The sample was centrifuged for $2465 \times \mathrm{g}$ for 20 min at $4{ }^{\circ} \mathrm{C}$ and the supernatant was discarded. To wash the residue, $50 \mathrm{~mL}$ of acetone was added and then vortexed for $30 \mathrm{~s}$, centrifuged at $2465 \times \mathrm{g}$ for 10 min at $4{ }^{\circ} \mathrm{C}$. After the wash, the supernatant was again discarded. To extract $\mathrm{PPO}$ and precipitate pectin, $6 \mathrm{~mL}$ of $0.1 \mathrm{M} \mathrm{pH} 7.0$ sodium phosphate buffer and $2 \mathrm{~mL}$ of $0.3 \mathrm{M}$ of calcium chloride was added to the residue. This solution was vortexed for $30 \mathrm{~s}$, placed on a rocker for $10 \mathrm{~min}$, and centrifuged at $2465 \times \mathrm{g}$ for $20 \mathrm{~min}$ at $4{ }^{\circ} \mathrm{C}$. The supernatant was reserved for analysis of PPO activity. For this, $15 \mu \mathrm{L}$ supernatant of PPO extract was aliquoted into a 96well plate in quadruplicate. Then, $285 \mu \mathrm{L}$ of $0.3 \mathrm{M}$ catechol and $0.1 \mathrm{M}$ pH 7.0 sodium phosphate buffer were added to wells with the extract. The microplate was quickly placed in a spectrophotometer, and the change in absorbance was measured at $420 \mathrm{~nm}$ for 3 min every $5 \mathrm{~s}$. PPO activity was defined by a 0.001 change in absorbance per $\min (\triangle \mathrm{A} 420 / \mathrm{min})$.

\section{Statistical analysis}

Results were expressed by the means \pm standard deviations of four different composite berry samples, with triplicate analysis of each aliquot. Results were analyzed using one-way ANOVA, with significance of $P<0.05$. Tukey's multiple comparisons were performed where ANOVA determined the data was significantly different. Data were analyzed using Rstudio (Rstudio, Boston, MA, U.S.A) and SAS (SAS Institute, Cary, NC, U.S.A) software, using total phenols, monomeric anthocyanins, proanthocyanidins, $\mathrm{PPO}, \mathrm{pH}$, titratable acidity, ${ }^{\circ}$ Brix, and ${ }^{\circ}$ Brix: acid as variables. 


\section{Results and discussion}

\section{Refrigeration and aronia berry quality} Aronia berry polyphenols

Initial values of total phenols, monomeric anthocyanins, and proanthocyanidins from fresh aronia berries were slightly lower than Bolling et al. (2015) (Fig. 1A-C). The difference may be due to weather conditions, geographical location, and other pre-harvest factors. Aronia berry polyphenol content fluctuated throughout storage at $4 \pm$ $2{ }^{\circ} \mathrm{C}$. Total phenols slightly increased at 2 weeks and declined for the rest of the 10 weeks (Fig. 1A). At 12 weeks, total phenols decreased by $21 \%$. Fluctuation occurred at the first 6 weeks and then reduced slightly until week 12 .
Monomeric anthocyanins followed a similar pattern as total phenols, as it had a slight increase at week 2, and then decreased $36 \%$ by week 10 (Fig. 1B). Proanthocyanidins decreased from 1.95 at 0 weeks to $1.52 \mathrm{mg} \mathrm{CE} / \mathrm{g}$ at 12 weeks (Fig. 1C). Former studies observed a similar trend with strawberries as total phenolics and anthocyanins increased at 2 weeks of storage (Šamec \& PiljacŽegarac 2011). Free polyphenols are more sensitive to light, PPO, and other enzymes, leading to reduced concentrations in plant tissue. The increased polyphenol content may also be attributed to phenylalanine ammonia-lyase (PAL) activated from cold-temperature stress (Lattanzio 2003). The anthocyanin decrease may
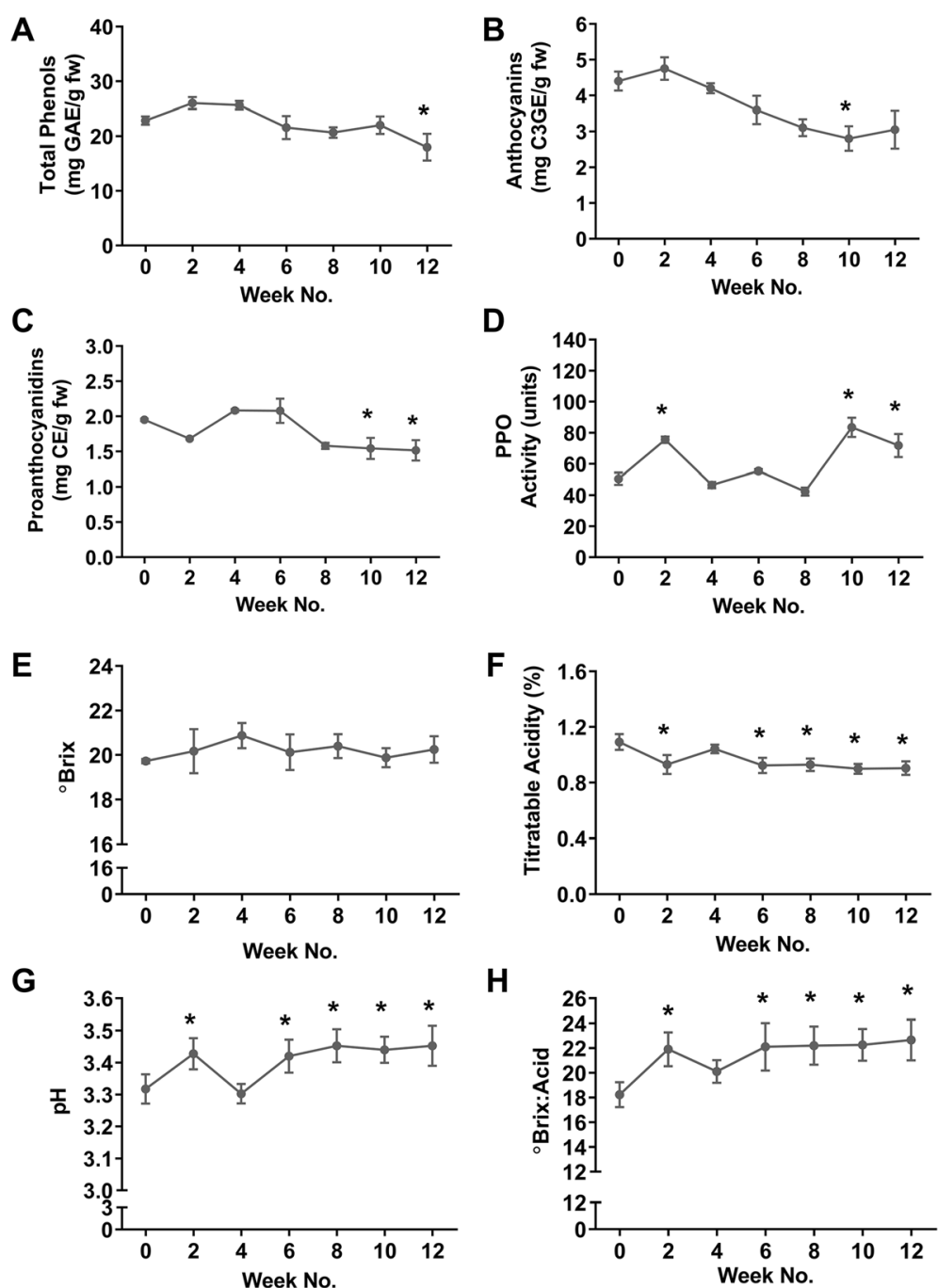

Fig. 1 Storage at $4{ }^{\circ} \mathrm{C}$ affects fresh aronia berry polyphenols. After refrigerated storage, aronia berry was analyzed for (A) extractable total phenols by Folin-Ciocalteu method as gallic acid equivalents (GAE); (B) extractable monomeric anthocyanins by pH differential method as cyandin-3glucoside equivalents (C3GE); (C) extractable proanthocyanins by 4-dimethylaminocinnamaldehyde (DMAC) method as catechin equivalents (CE); (D) extractable polyphenol oxidase (PPO) activity; (E) juice ${ }^{\circ}$ Brix, (F) juice titratable acidity; (G) juice $\mathrm{pH}$; and (E) juice ${ }^{\circ}$ Brix: acid ratio. Week 0 represents analysis of unfrozen fresh berries picked within $6 \mathrm{~h}$. A unit of PPO activity is a 0.001 change in absorbance per min ( $\triangle \mathrm{A} 420 / \mathrm{min})$. Data are means \pm standard deviation of $n=4$ aliquots aronia plants, with triplicates for each plant. Data were analyzed by one-way ANOVA with Tukey's multiple comparison test vs. the fresh sample, ${ }^{*} P<0.05$ vs. time 0 
be explained by increased $\mathrm{pH}$, which destabilizes anthocyanins (Wu et al. 2010). In contrast, refrigerated storage increases anthocyanins and total phenols in blackberries, cherries, plums, and other fruits (Šamec \& Piljac-Žegarac 2011). Nevertheless, polyphenols' reaction patterns differ during refrigerated storage due to phenolic composition, ripeness, and enzyme activity (Wu et al. 2010).

\section{Aronia berry PPO activity}

During $4 \pm 2{ }^{\circ} \mathrm{C}$ storage of fresh aronia berry, its PPO activity increased by $49 \%$ at week 2 , then decreased at week 4 , remaining consistent for the next 4 weeks, and then increased by $65 \%$ at week 10 (Fig. 1D). Visual inspection over the 12 weeks did not reveal the obvious color or other physical changes. However, at week 13, mold growth was observed. The PPO trend for aronia berry was similar to that reported in pear, as PPO activity increased at 2 weeks (Yan et al. 2013). This increase may be from damage from cooling the berries, thus increasing the expression of PPO activity.

Although PPO enzymes did not significantly affect or correlate with the polyphenol concentrations during storage, other enzymes may have caused changes in polyphenols. The phenylalanine ammonia-lyase (PAL), an enzyme that acts as a bridge between the primary pathway (shimiki pathway) and the secondary pathway (phenylpropanoid pathway) in the phenolic metabolism, may increase in berries due to low-temperature stress (Lattanzio 2003). In one study, cherries, sour cherries, strawberries, and red currents increased in their anthocyanin and or flavonoid content during storage at $4{ }^{\circ} \mathrm{C}$ (Piljac-Žegarac \& Šamec 2011). Wu et al. (2010) demonstrated blackberries' anthocyanin concentration also rose during storage at $2{ }^{\circ} \mathrm{C}$.

Conversely, enzymes, including peroxidase (POD) and $\mathrm{PPO}$, are linked to polyphenol metabolism, causing a reduction in anthocyanins and other polyphenols (Lattanzio 2003). POD enzymes are highly thermostable that cause an oxidation reaction when hydrogen peroxide is present (Nokthai et al. 2010). Studies concluded that PPO's involvement in oxidizing polyphenols is hydrolyzing a monophenol to an o-diphenol, creating an oquinone, causing a brown color to form or lose pigment in fruits (Nokthai et al. 2010). Future studies need to examine the correlation of polyphenol concentrations to other enzymes during storage studies.

\section{Aronia berry ${ }^{\circ}$ brix and acid}

During refrigerated storage, aronia berry juice ${ }^{\circ}$ Brix fluctuated with no significant difference between the 12 weeks (Fig. 1E). Titratable acidity declined 17\% during at week 12 of storage (Fig. 3F). However, after week 6, titratable acidity stayed relatively consistent. Aronia berry $\mathrm{pH}$ increased at weeks 2, 6, 8, 10, and 12 (Fig. 3G). A similar trend was observed for the ${ }^{\circ}$ Brix: acid content, increasing by $24 \%$ at the end of 12 weeks (Fig. $3 \mathrm{H}$ ).

Changes in ${ }^{\circ}$ Brix and acid during storage can change the taste of fruit (Yanyun Zhao 2007, pp. 213-214). Refrigeration can reduce titratable acidity loss by slowing down the primary metabolism (Brizzolara et al. 2020). However, the sugar-acid metabolism is not entirely stopped and can still impact acidity and ${ }^{\circ}$ Brix. Previous studies reported refrigerated storage increases $\mathrm{pH}$ and decreases titratable acidy in blackberries (Kim et al. 2015; Perkins-Veazie et al. 1999; Wu et al. 2010) and mangoes (Hossain et al. 2014).

\section{Long-term frozen storage of aronia berry Aronia berry polyphenols}

Storage of aronia berry at $-20 \pm 2{ }^{\circ} \mathrm{C}$ changed total phenols at only one time point. At $6 \mathrm{mo}$. total phenols were increased, but then declined again at 8 mo. (Fig. 2A). Thus, at 8 mo., total phenols remained the same as that as the fresh aronia berries. Anthocyanins (Fig. 2B) and proanthocyanidins (Fig. 2C) were also increased only at 6 mo. of frozen storage.

The effect of frozen storage on fruit polyphenols depends on the type of fruit, its protein/ sugar content (both protein and sugar have a cryoprotective effect), phenolic composition, biosynthesis during post-harvest, enzyme concentration, preharvest factors (ripeness, location, weather, cultivation method, season), and cultivar (Neri et al. 2020; Šamec \& Piljac-Žegarac 2014). Past studies have described little change to total phenols during storage of raspberries, blueberries, cherries, blackberries, and grapes (González et al. 2003; Cocetta et al. 2015; Šamec \& Piljac-Žegarac 2014). Šamec \& PiljacŽegarac (2014) observed the most fluctuation in strawberries during frozen storage, increasing $13 \%$ at 3 mo., followed by a $40 \%$ decrease at 6 mo., and a 19\% increase at 12 mo. In contrast, other studies report decreased total phenolic changes during frozen storage. After 10 mo. at $-20{ }^{\circ} \mathrm{C}$, total phenols decreased by $28 \%$ for blueberries, $42 \%$ for blackberries, and $47 \%$ for raspberries (Poiana et al. 2010). However, results are inconsistent between different studies as polyphenol content of various berries may decrease (Chaovanalikit \& Wrolstad 2004), increase (de Ancos et al. 2000; Urbanyi \& Horti 1992), or remain unchanged (Cocetta et al. 2015; Khattab et al. 2015). The increase in polyphenol content is mainly attributed to cellular degradation, causing a release of polyphenols from the cell structure and increasing extractability (Sablani 2015). This may explain the observed increase and subsequent decrease of aronia berry phenolics as free polyphenols' degradation rates are increased. 

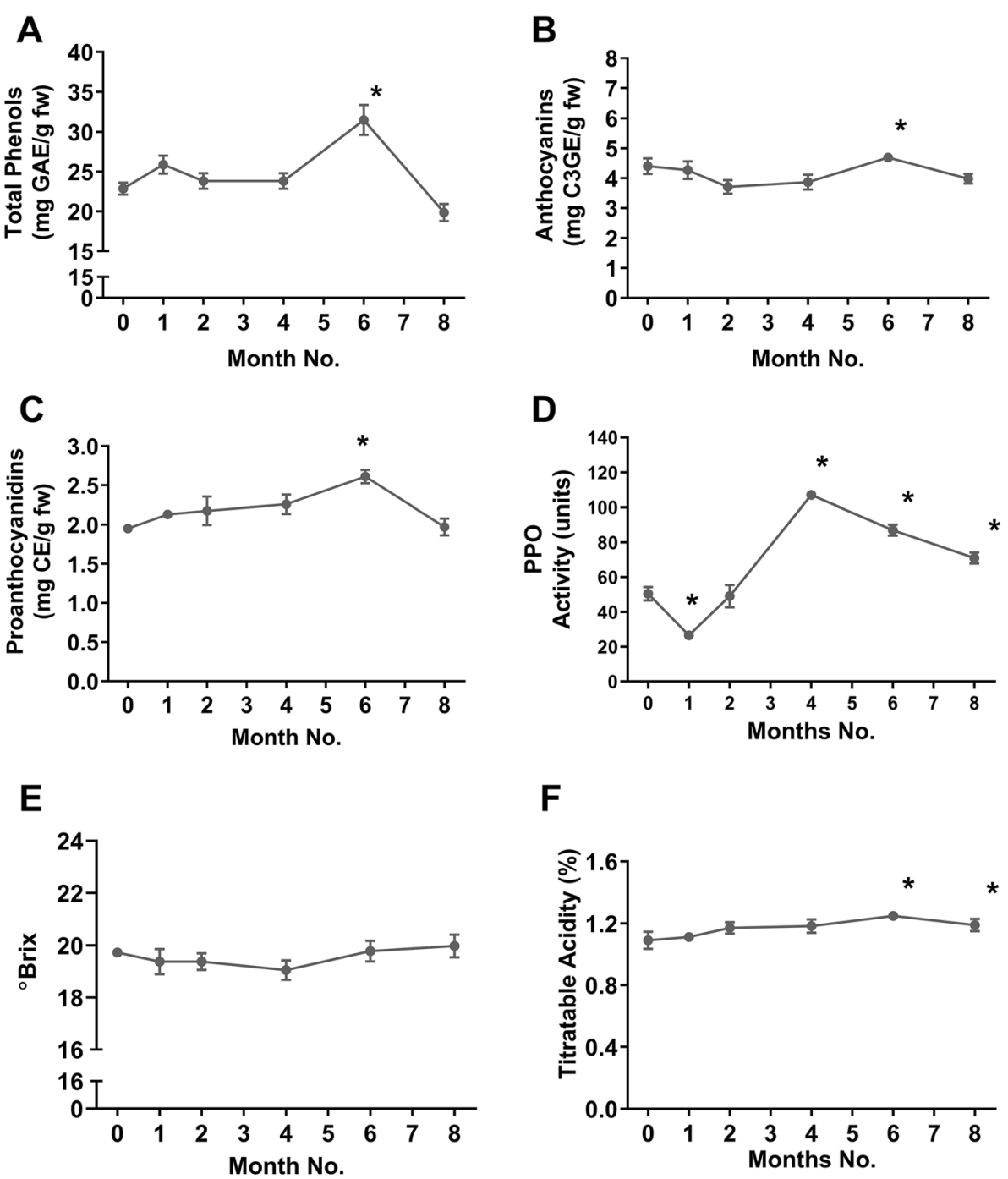

$\mathbf{F}$
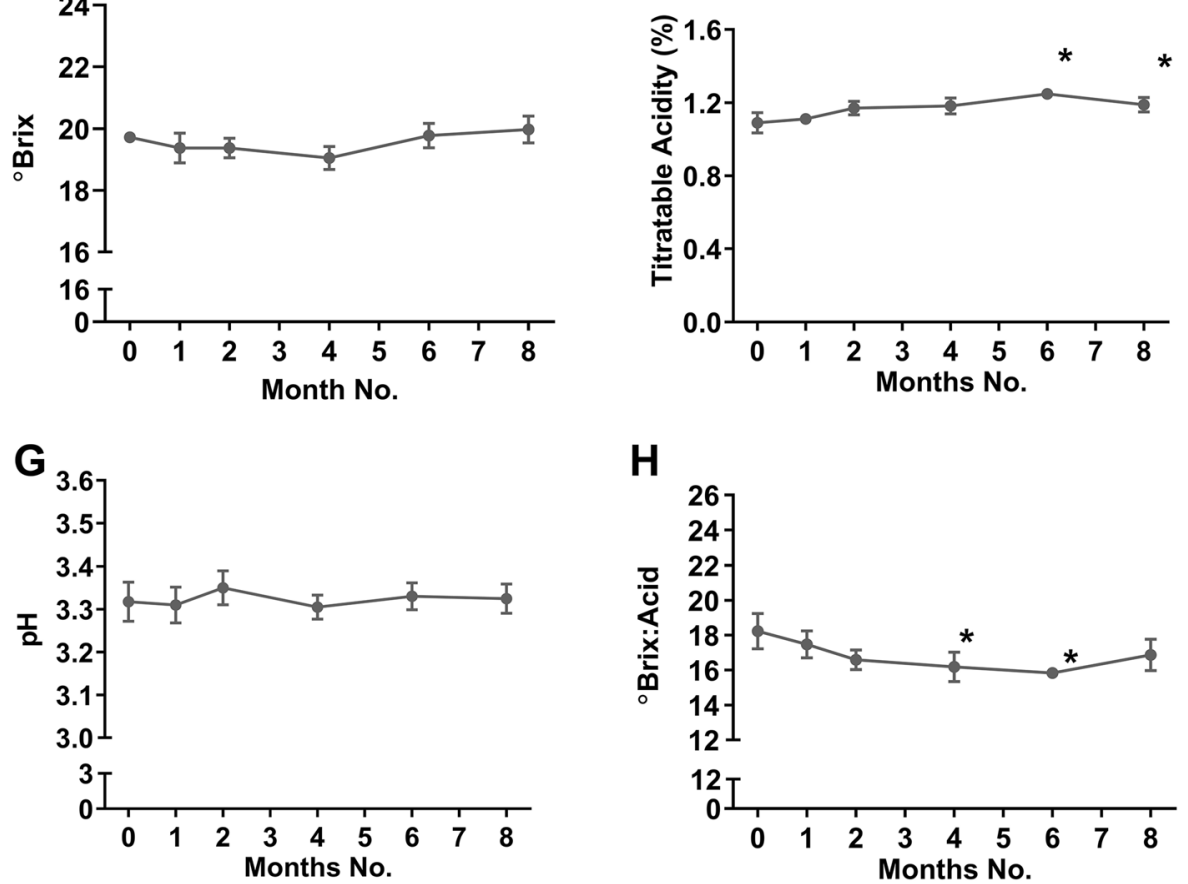

Fig. 2 Storage at $-20^{\circ} \mathrm{C}$ affects aronia berry polyphenol content. After frozen storage, aronia berry was analyzed for $(\mathbf{A})$ extractable total phenols by Folin-Ciocalteu method as gallic acid equivalents (GAE); (B) extractable monomeric anthocyanins by pH differential method as cyandin-3glucoside equivalents (C3GE); (C) extractable proanthocyanins by 4-dimethylaminocinnamaldehyde (DMAC) method as catechin equivalents (CE); (D) extractable polyphenol oxidase (PPO) activity; (E) juice ${ }^{\circ}$ Brix, (F) juice titratable acidity; (G) juice pH; and (E) juice ${ }^{\circ}$ Brix: acid ratio. Week 0 represents analysis of unfrozen fresh berries picked within $6 \mathrm{~h}$. A unit of PPO activity is a 0.001 change in absorbance per min ( $\triangle \mathrm{A} 420 / \mathrm{min})$. Data are means \pm standard deviation of $n=4$ aliquots aronia plants, with triplicates for each plant. Data were analyzed by one-way ANOVA with Tukey's multiple comparison test vs. the fresh sample, ${ }^{*} P<0.05$ vs. time 0 


\section{Frozen aronia berry PPO activity}

Prolonged frozen storage increased aronia berry PPO activity (Fig. 2D). Aronia berry PPO activity was reduced at 1 mo. of frozen storage, but at 4 mo., PPO activity increased by $111 \%$ compared to the fresh aronia berries. At subsequent months, PPO activity was decreased from the peak 4 mo. activity. The decrease is to be expected as PPO activity eventually decreases during storage (Nokthai et al. 2010). The increase in activity in the first 4 months is likely a result of tissue damage from freezing the aronia berries (Concellón et al. 2004; Khattab et al., 2015; Lattanzio 2003). The formation of large ice crystals can damage cells, releasing PPO and increasing reactivity with polyphenols. Similar results, with an increase in PPO activity during long-term frozen storage, were seen in dates (Alhamdan 2016) and papaya (Cano et al. 1998). However, the contribution of increased PPO to aronia polyphenol levels in frozen berries is expected to be low because PPO activity is reduced below $7{ }^{\circ} \mathrm{C}$ (Singh, B., 2018).

\section{Frozen aronia berry ${ }^{\circ}$ brix and acid}

Frozen storage had a limited impact on aronia berry ${ }^{\circ}$ Brix, acid, pH, and ${ }^{\circ}$ Brix: acid (Fig. 2E-H). At 6 mo., titratable acidity was increased by $14 \%$ from initial values, but at 8 mo., ${ }^{\circ}$ Brix: acid was similar to initial values.

Studies have indicated that when frozen, acids in berries and citric fruits are more stable than other fruits such as peaches (Dawson et al. 2020; Skrede G 1996). Additionally, berries contain different respiration rates: blueberries, currants, and cranberries have slower respiration rates and a longer storage life than blackberries and raspberries (Yanyun Zhao 2007, pp. 207-223). Aronia berries may contain lower respiration and acid metabolism rates, causing only slight changes in titratable acidity during storage.

\section{Frozen temperature cycling of frozen aronia berry Aronia berry polyphenols during temperature cycling}

Temperature cycling initially decreased aronia berry total phenols from 6 to 12 cycles, but values normalized to baseline after 18 and 24 cycles (Fig. 3A). Aronia berry anthocyanins were decreased 24 to $33 \%$ after 12 and 18 cycles (Fig. 3B). In contrast, aronia berry proanthocyanidins were not affected by up to 24 temperature cycles (Fig. 3C). The increase in total phenols can be explained by ice-induced cellular destruction, thus increasing rates of polyphenol extraction during analysis. Apparently, these changes are independent of anthocyanins and proanthocyanidins, indicating that low molecular weight phenolics are impacted more than large molecular weight proanthocyanidins. Therefore, anthocyanin extraction may increase but be destabilized during redistribution.
Holzwarth et al. (2012) described strawberries subjected to temperature cycling and reported increased total phenols but reduced anthocyanins. The recovery of strawberry anthocyanins in microwaved berries was higher than those thawed at 4 or $25^{\circ} \mathrm{C}$ (Holzwarth et al. 2012). Anthocyanins are degraded as the temperature cycles increase damage to cell structures, allowing anthocyanins to be released and exposed to a higher $\mathrm{pH}$, leading to the formation of less-stable quinoidal bases, carbinol pseudo-bases, or chalcones (Sablani 2015). Additionally, exposed anthocyanins are more susceptible to enzymes, ascorbic acid, metal ions, oxygen, and light (Holzwarth et al. 2012; Sablani 2015).

\section{Aronia berry PPO activity after temperature cycling}

At 18 cycles, aronia berry PPO activity increased $31 \%$ from baseline but returned to baseline at 24 cycles (Fig. 3D). PPO activity and anthocyanin content were not statistically significant $(\mathrm{r}=-0.880, \quad p=0.49)$. Temperature cycling had a limited impact on aronia berry PPO activity relative to refrigerated and frozen storage.

The temperature-cycling method used a microwave on the defrost setting to obtain homogeneous defrosting time for all berries ( $\mathrm{Li} \&$ Sun, 2002). Former studies used a microwave as a technique for temperature-cycling experiments and concluded no deterioration in polyphenols (Holzwarth et al. 2012). However, there is no certainty the microwave did not affect the PPO enzymes in the aronia berries, causing lower PPO activity than frozen and refrigeration storage.

\section{Aronia berry ${ }^{\circ}$ brix and acid after temperature cycling}

Aronia berry ${ }^{\circ}$ Brix decreased by $7 \%$ at cycle 12 , but gradually returned to baseline by 24 cycles (Fig. 3E). The increase in ${ }^{\circ}$ Brix can also be attributed to the cell damage during freezing and thawing, allowing the sugars to be released from the cells, increasing extraction from berries when juiced. Additionally, the fluctuation of ${ }^{\circ}$ Brix may be due to a decrease in titratable acidy, anthocyanin content, and the pectin cell wall starting to dissolve (Yanyun Zhao 2007, pp. 213-214). However, temperature cycling did not affect titratable acidity and $\mathrm{pH}$ (Fig. 3F, G). ${ }^{\circ}$ Brix: acid decreased at cycle 12 , due to the decrease in ${ }^{\circ}$ Brix (Fig. $3 \mathrm{H}$ ).

\section{Aronia berry color after temperature cycling}

Frozen temperature cycling significantly modulated aronia berry color, despite the limited impact on polyphenol content (Table 1, Fig. 4, Fig. 5A-B). The average of lightness $\left(\mathrm{L}^{*}\right)$, redness $\left(\mathrm{a}^{*}\right)$, and blueness $\left(b^{*}\right)$ of fresh berries decreased progressively, leading 

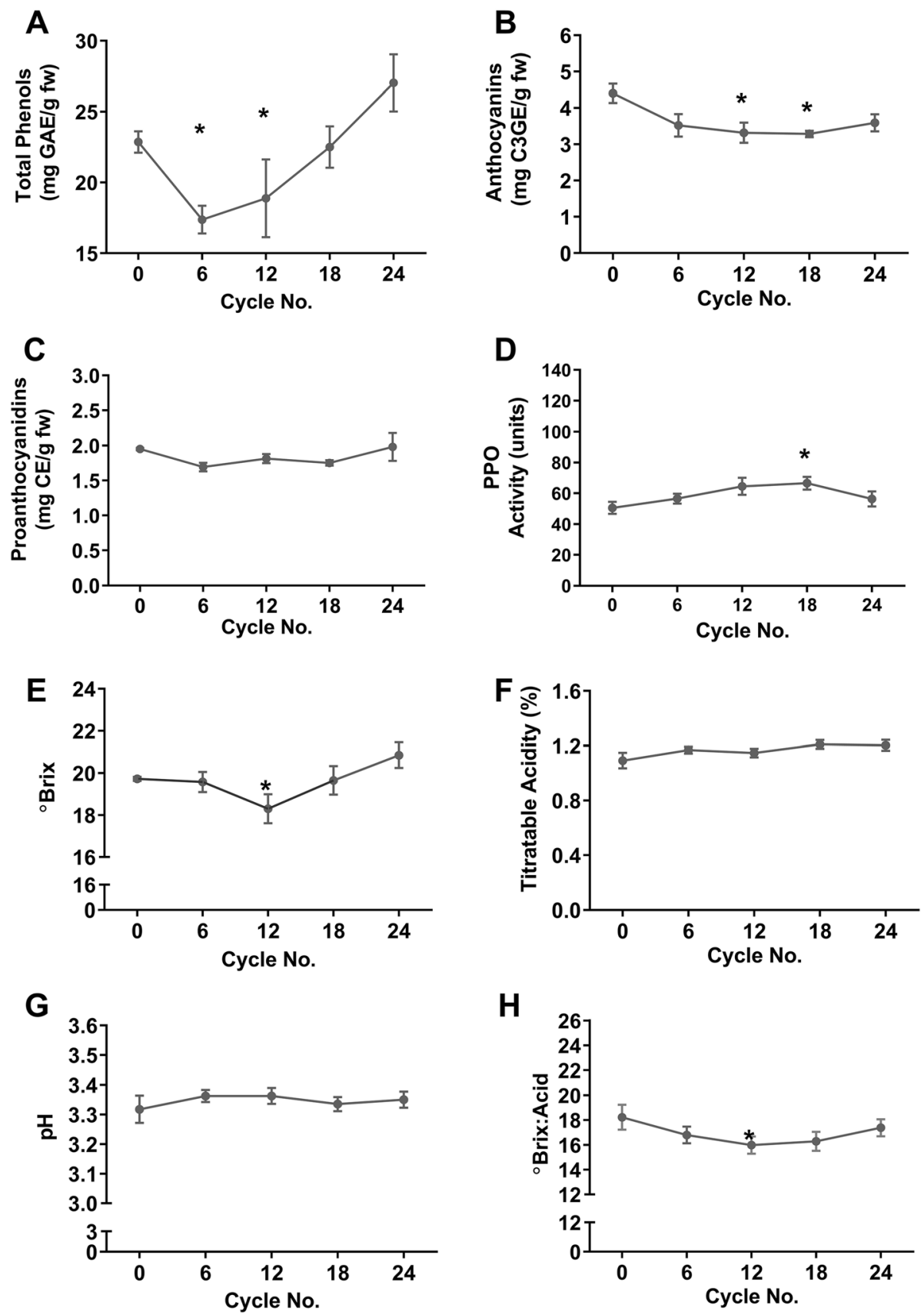

Fig. 3 Temperature cycling affects aronia berry polyphenols. Aronia berry was subjected to repeated frozen temperature cycling and analyzed for (A) extractable total phenols by Folin-Ciocalteu method as gallic acid equivalents (GAE); (B) extractable monomeric anthocyanins by pH differential method as cyandin-3-glucoside equivalents (C3GE); (C) extractable proanthocyanins by 4-dimethylaminocinnamaldehyde (DMAC) method as catechin equivalents (CE); (D) extractable polyphenol oxidase (PPO) activity; (E) juice ${ }^{\circ}$ Brix, (F) juice titratable acidity; (G) juice pH; and (E) juice ${ }^{\circ}$ Brix: acid ratio. Week 0 represents analysis of unfrozen fresh berries picked within $6 \mathrm{~h}$. A unit of PPO activity is a 0.001 change in absorbance per $\min (\triangle A 420 / \mathrm{min})$. Data are means \pm standard deviation of $n=4$ aliquots aronia plants, with triplicates for each plant. Data were analyzed by one-way ANOVA with Tukey's multiple comparison test vs. the fresh sample, ${ }^{*} P<0.05$ vs. cycle 0

to increased total color change $\left(\Delta E^{*}\right)$. The aronia berry reached the darkest color at 24 cycles, with $9.99 \mathrm{~L}^{*}$. Temperature cycling caused aronia berries to become bluer (less yellow) and more green (less red) with more induced temperature cycle treatments. The increase in darkness may be attributed to the increase in ice crystal formation during the temperature cycles, causing the cells to rupture, losing water from the 
Table 1 Colorimetric analysis of halved aronia berries after temperature cycling

\begin{tabular}{llll}
\hline No. of temperature cycles & $\mathbf{L}^{*}$ & $\mathbf{a}^{*}$ & $\mathbf{b}^{*}$ \\
\hline 0 & $22.0 \pm 4.3^{\mathrm{a}}$ & $20.2 \pm 0.1^{\mathrm{a}}$ & $8.79 \pm 0.96^{\mathrm{a}}$ \\
6 & $16.2 \pm 2.3^{\mathrm{b}}$ & $13.1 \pm 1.2^{\mathrm{b}}$ & $5.56 \pm 0.82^{\mathrm{b}}$ \\
12 & $13.2 \pm 1.9^{\mathrm{b}, \mathrm{c}}$ & $11.3 \pm 1.1^{\mathrm{c}}$ & $4.66 \pm 0.91^{\mathrm{c}}$ \\
18 & $12.1 \pm 0.6^{\mathrm{c}}$ & $10.8 \pm 1.1^{\mathrm{c}}$ & $3.87 \pm 0.37^{\mathrm{c}, \mathrm{d}}$ \\
24 & $9.99 \pm 0.56^{\mathrm{c}}$ & $9.59 \pm 0.73^{\mathrm{d}}$ & $3.30 \pm 0.18^{\mathrm{d}}$ \\
\hline
\end{tabular}

${ }^{1}$ Data are means \pm standard deviation of $n=4$ aliquots aronia plants, with duplicate analysis for each plant. Data were analyzed by one-way ANOVA with Tukey's multiple comparison test $P<0.05$. Identical letters in the same column indicate values are not significantly different

vacuole, thus compressing cell walls (Dawson et al. 2020). The color changes observed here support the hypothesis that anthocyanins and other phenolics are redistributed by temperature cycling.

\section{Scanning electron microscopy (SEM) of aronia berry subjected to temperature cycling}

Temperature cycling during frozen storage led to cellular deformation in the aronia berries (Fig. 5C, D). Berries that were not subject to temperature cycling had more predominant and intact cell structures. Cell damage was observed at 6 cycles and increased progressively through the 24 cycles. Temperature cycling damaged cell walls and led to cell shrinkage. Cell wall fusion is predominantly observed at cycles 18 and 24 . The thick white tissue in the images are deformed cell walls and enlarged weak intercellular spaces (Delgado \& Rubiolo 2005; Li et al. 2018). When the cell wall is damaged, the pectin and hemicellulose connect to other cell walls, attributing to the enlargement of the intercellular space $(\mathrm{Li}$ et al.

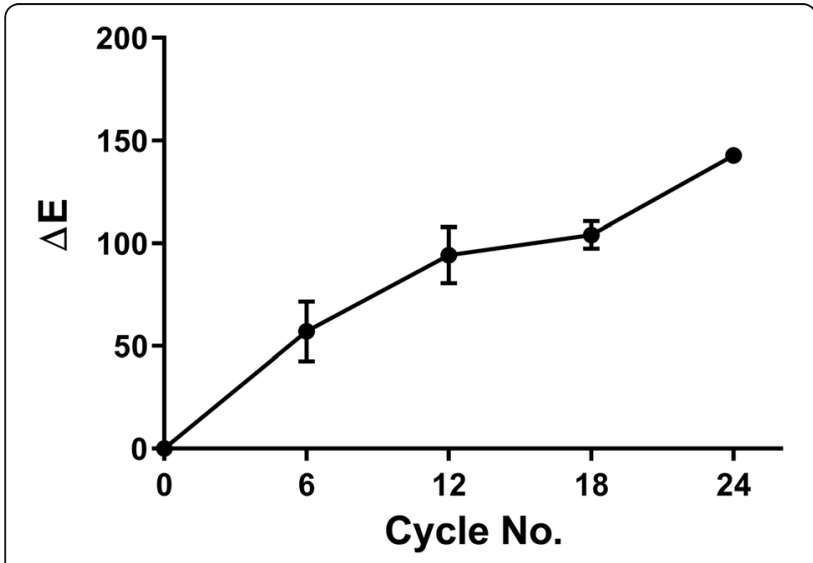

Fig. 4 Temperature cycling increases $\Delta \mathrm{E}$ of halved aronia berries. Data are means \pm standard deviation of $n=4$ aliquots aronia plants, with duplicate analysis of for each aliquot. Data were analyzed by one-way ANOVA with Tukey's multiple comparison test $(P<0.05)$. All cycles were significantly different from other observations
2018). The cellular deformation induced by freezing has also been reported for strawberries (Delgado \& Rubiolo 2005), apples (Chassagne-Berces et al. 2009), and blueberries (Nowak et al. 2018).

There were minor variations in the extent of damage between berries from the same number of temperature cycles, especially in cycles 18 and 24 . The difference in damage could be due to berry size, position in the bag during thawing, and the berry position in the bag during storage. The size of the berry can impact the temperature of the berry during thawing. Furthermore, the position in the bag during storage and thawing affects the berry because the energy required to cool down or heat up the berry is more accessible to berries located on the outer perimeter. Thus, more significant variation in damage is likely to occur in the cells when berries are exposed to more temperature cycles.

When the berries were in the freezer, not all the water was frozen due to the sugar content in aronia berries (Allan-Wojtas et al. 2006). In Poiana et al. 2010 , berries stored at $-18{ }^{\circ} \mathrm{C}$ included $89 \%$ of total water frozen, and at $-30{ }^{\circ} \mathrm{C}, 91 \%$ were completely frozen. The unfrozen water migrates to outer cells, containing less water, generating larger ice crystals and recrystallization (Allan-Wojtas et al. 2006). The crystal growth provokes punctured cells and cellular shrinkage, causing deformation. Recrystallization was also created by the temperature cycles. After being thawed, berries placed in the freezer may have gained larger ice crystals replacing smaller ice crystals and caused damage and shrinkage to the cells of the aronia berry.

Aronia berries in our study were exposed to slow freezing. A slower rate causes large ice crystals with less nucleation because the water has more time to migrate out of the cell, causing large ice crystals in one area. The large sharp crystals, formed during slow freezing, may have punctured the aronia berry cell organelles (vacuole), causing a release of water and other contents from the cell (De Ancos et al. 2006; Phothiset \& Charoenrein 2013).

\section{Conclusions}

Prolonged refrigeration of fresh aronia berry at $4 \pm$ $2{ }^{\circ} \mathrm{C}$ for up to 12 weeks led to more significant polyphenols loss than frozen storage at $-20 \pm 2{ }^{\circ} \mathrm{C}$ and up to 24 temperature cycles. However, 12 weeks of $4{ }^{\circ} \mathrm{C}$ refrigeration only led to modest losses in polyphenols, with anthocyanins having the most loss among phenolics, at $36 \%$ of initial values. Reducing temperatures closer to the freezing point of berries would be expected to lower rates of degradation further. Freezing and temperature cycling led to a redistribution of 
A

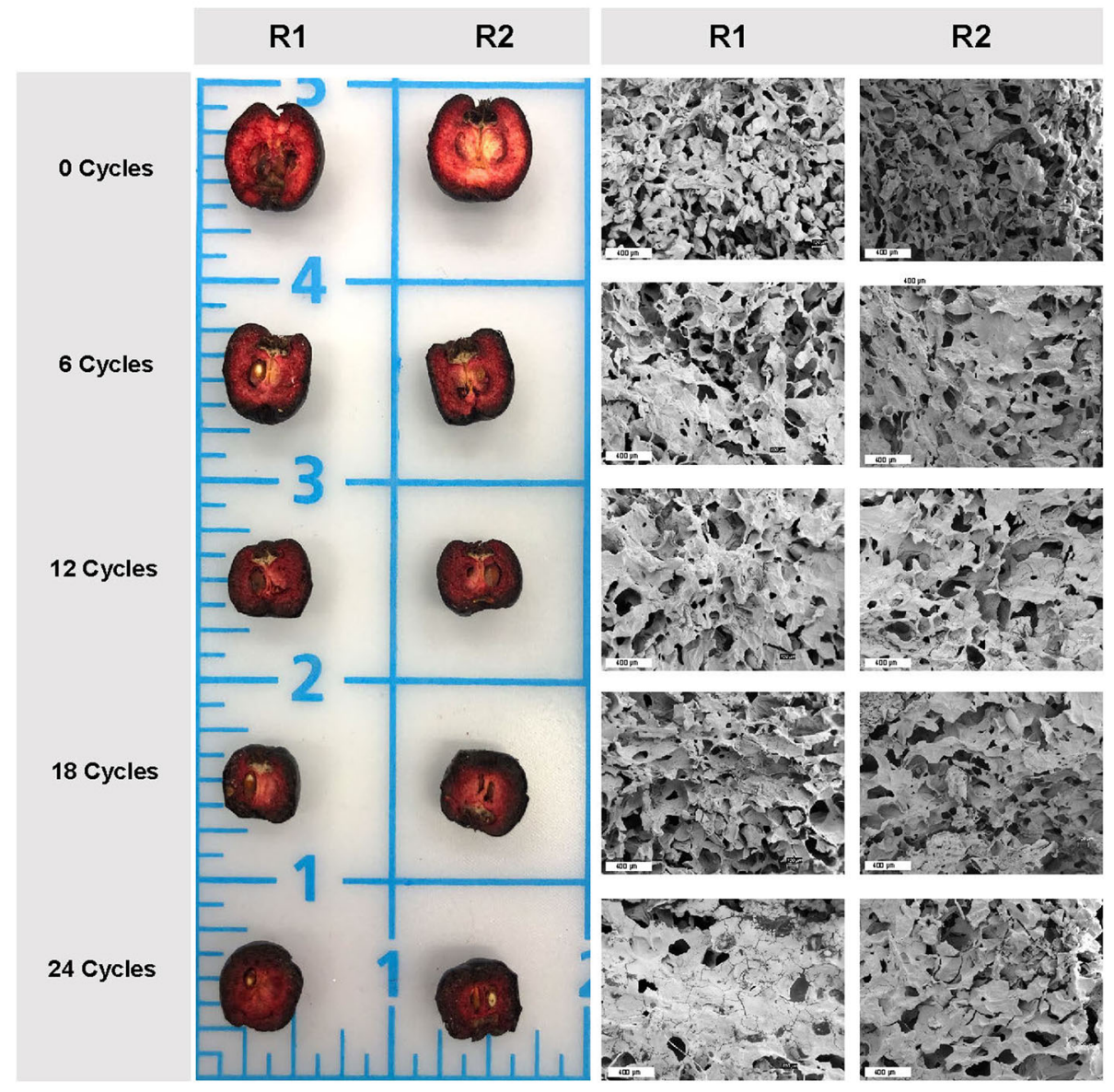

Fig. 5 Frozen storage temperature cycling affects aronia berry structure. (A) Visual Appearance of lyophilized halved aronia berries after temperature cycling (B) SEM images of aronia berries subjected to temperature cycles. SEM magnification 50x. Images are $N=2$ different berries from each temperature cycle polyphenols, which increased extractability and likely contributed to some degradation during prolonged frozen storage. As with refrigerated storage, aronia berry anthocyanins were most susceptible to degradation than other phenolics. Thus, refrigeration and frozen storage are viable means to preserve aronia berry polyphenol content and quality.

\section{Acknowledgements}

Not applicable.

\section{Authors' contributions}

Erica King: Conceptualization; Methodology; Investigation; Writing - Original Draft; Andrea Noll: Methodology, Investigation; Susan Glenn: Formal analysis; Bradley Bolling: Conceptualization; Supervision; Funding acquisition; Writing - Review \& Editing. The final document was read and approved by the authors.

\section{Authors' information}

Not applicable.
Funding

Supported by the Fritz Friday Chair for Vegetable Processing Research, College of Agriculture to BWB.

Availability of data and materials

Please contact Dr. Bolling for data requests.

\section{Declarations}

Ethics approval and consent to participate Not applicable.

\section{Consent for publication}

Not applicable.

\section{Competing interests}

The authors declare that they have no competing interests.

\section{Author details}

'Department of Food Science, University of Wisconsin-Madison, 1605 Linden Dr., Madison, WI 53706, USA. ${ }^{2}$ Department of Statistics, Medical Sciences Center, University of Wisconsin-Madison, 1300 University Ave Rm 1220, Madison, WI 53706, USA. 
Received: 26 October 2021 Accepted: 22 November 2021

\section{Published online: 24 January 2022}

\section{References}

Alhamdan, A. (2016). Quality changes in fresh date fruits (Barhi) during individual quick freezing and conventional slow freezing. Pakistan Journal of Agricultural Sciences, 53(4), 917-924. https://doi.org/10.21162/PAKJAS/16.4021.

Allan-Wojtas, P., Goff, H. D., Stark, R., \& Carbyn, S. (2006). The effect of freezing method and frozen storage conditions on the microstructure of wild blueberries as observed by cold-stage scanning electron microscopy. Scanning, 21(5), 334-347. https://doi.org/10.1002/sca.4950210507.

Bolling, B. W., Taheri, R., Pei, R., Kranz, S., Yu, M., Durocher, S. N., \& Brand, M. H. (2015). Harvest date affects aronia juice polyphenols, sugars, and antioxidant activity, but not anthocyanin stability. Food Chemistry, 187, 189-196. https:// doi.org/10.1016/j.foodchem.2015.04.106.

Brizzolara, S., Manganaris, G. A., Fotopoulos, V., Watkins, C. B., \& Tonutti, P. (2020) Primary metabolism in fresh fruits during storage. Frontiers in Plant Science, 11, 80. https://doi.org/10.3389/fpls.2020.00080.

Bulhões Bezerra Cavalcante, T. A., dos Santos Funcia, E., \& Wilhelms Gut, J. A. (2021). Inactivation of polyphenol oxidase by microwave and conventional heating: Investigation of thermal and non-thermal effects of focused microwaves. Food Chemistry, 340, 127911. https://doi.org/10.1016/j. foodchem.2020.127911.

Cano, M. P., Lobo, M. G., \& De Ancos, B. (1998). Peroxidase and polyphenol oxidase in long-term frozen stored papaya slices. Differences among hermaphrodite and female papaya fruits. Journal of the Science of Food and Agriculture, 76(1), 135-141. https://doi.org/10.1002/(SICI)1097-0010(199801 )76:1<135::AID-JSFA949>3.0.CO;2-9.

Chaovanalikit, A., \& Wrolstad, R. E. (2004). Total anthocyanins and total phenolics of fresh and processed cherries and their antioxidant properties. Journal of Food Science, 69(1), FCT67-FCT72. https://doi.org/10.1111/j.1365-2621.2004. tb17858.x.

Chassagne-Berces, S., Poirier, C., Devaux, M.-F., Fonseca, F., Lahaye, M., Pigorini, G., ... Guillon, F. (2009). Changes in texture, cellular structure and cell wall composition in apple tissue as a result of freezing. Food Research International, 42(7), 788-797. https://doi.org/10.1016/j.foodres.2009.03.001.

Cocetta, G., Mignani, I., \& Spinardi, A. (2015). Effects of long-term storage on highbush blueberry (Vaccinium corymbosum L.) antioxidant quality. Acta Horticulturae, 6(1071), 477-482.

Concellón, A., Añón, M. C., \& Chaves, A. R. (2004). Characterization and changes in polyphenol oxidase from eggplant fruit (Solanum melongena L.) during storage at low temperature. Food Chemistry, 88(1), 17-24. https://doi.org/10.1 016/j.foodchem.2004.01.017.

Dawson, P., Al-Jeddawi, W., \& Rieck, J. (2020). The effect of different freezing rates and long-term storage temperatures on the stability of sliced peaches. International Journal of Food Science, 2020(1), 1-17. https://doi.org/10.1155/2 020/9178583.

de Ancos, B., Ibañez, E., Reglero, G., \& Cano, M. P. (2000). Frozen storage effects on anthocyanins and volatile compounds of raspberry fruit. Journal of Agricultural and Food Chemistry, 48(3), 873-879. https://doi.org/10.1021/ jf990747C.

De Ancos, B., Snchez-Moreno, C., De Pascual-Teresa, S., \& Cano, M. P. (2006). Fruit freezing principles. Handbook of Fruits and Fruit Processing, 1, 59-79. https:// doi.org/10.1002/9780470277737.ch4.

Delgado, A. E., \& Rubiolo, A. C. (2005). Microstructural changes in strawberry after freezing and thawing processes. LWT - Food Science and Technology, 38(2), 135-142. https://doi.org/10.1016/j.lwt.2004.04.015.

Diaconeasa, Z. (2018). Time-dependent degradation of polyphenols from thermally-processed berries and their in vitro antiproliferative effects against melanoma. Molecules, 23(10), 2534. https://doi.org/10.3390/ molecules 23102534 .

Georgiev, D., \& Ludneva, D. (2009). Possibilities for production of nectars and purees from fruits of black chokeberry (Aronia melanocarpa). Acta Horticulturae, 825(825), 595-598. https://doi.org/10.17660/ActaHortic.2009. 825.95

González, E. M., de Ancos, B., \& Cano, M. P. (2003). Relation between bioactive compounds and free radical-scavenging capacity in berry fruits during frozen storage. Journal of the Science of Food and Agriculture, 83(7), 722-726. https:// doi.org/10.1002/jsfa.1359.

Hajji, W., Bellagha, S., \& Allaf, K. (2019). Effect of partial drying intensity, frozen storage and repeated freeze-thaw cycles on some quality attributes of dehydrofrozen quince fruit. Journal of Food Measurement and Characterization, 12(1), 353-365. https://doi.org/10.1007/s11694-019-00297-z.

Holcroft, D. M., \& Kader, A. A. (1999). Controlled atmosphere-induced changes in $\mathrm{pH}$ and organic acid metabolism may affect color of stored strawberry fruit. Postharvest Biology and Technology, 17(1), 19-32. https://doi.org/10.1016/S092 5-5214(99)00023-X.

Holzwarth, M., Korhummel, S., Carle, R., \& Kammerer, D. R. (2012). Evaluation of the effects of different freezing and thawing methods on color, polyphenol and ascorbic acid retention in strawberries (Fragariaxananassa Duch.). Food Research International, 48(1), 241-248. https://doi.org/10.1016/j.foodres.2012.04.004.

Hossain, M. A., Rana, M. M., Kimura, Y., \& Roslan, H. A. (2014). Changes in biochemical characteristics and activities of ripening associated enzymes in mango fruit during the storage at different temperatures. BioMed Research International, 2014(1), 1-11. https://doi.org/10.1155/2014/232969.

Kahramanoglu, I. (Ed.) (2017). Postharvest Handling. InTech. https://doi.org/10. $5772 / 66538$

Khattab, R., Celli, G. B., Ghanem, A., \& Brooks, M. S.-L. (2015). Effect of frozen storage on polyphenol content and antioxidant activity of haskap berries (Lonicera caerulea L.). Journal of Berry Research, 5(4), 231-242. https://doi.org/1 $0.3233 / J B R-150105$.

Kim, M. J., Perkins-Veazie, P., Ma, G., \& Fernandez, G. (2015). Shelf life and changes in phenolic compounds of organically grown blackberries during refrigerated storage. Postharvest Biology and Technology, 110, 257-263. https://doi.org/1 0.1016/j.postharvbio.2015.08.020.

King, E. S., \& Bolling, B. W. (2020). Composition, polyphenol bioavailability and health benefits of aronia berry: A review. Journal of Food Bioactives, 11, 1330. https://doi.org/10.31665/JFB.2020.11235.

Lattanzio, V. (2003). Bioactive polyphenols: Their role in quality and storability of fruit and vegetables. Journal of Applied Botany, 77(5/6), 128-146.

Lee, J., Durst, R. W., Wrolstad, R. E., Eisele, T., Giusti, M. M., Hach, J., et al. (2005). Determination of total monomeric anthocyanin pigment content of fruit juices, beverages, natural colorants, and wines by the $\mathrm{pH}$ differential method: Collaborative study. Journal of AOAC International, 88(5), 1269-1278. https:// doi.org/10.1093/jaoac/88.5.1269.

Li, B., \& Sun, D. -W. (2002). Novel methods for rapid freezing and thawing of foods - a review. Journal of Food. 54(3), 175-182. https://doi.org/10.1016/S02 60-8774(01)00209-6.

Li, D., Zhu, Z., \& Sun, D.-W. (2018). Effects of freezing on cell structure of fresh cellular food materials: A review. Trends in Food Science \& Technology, 75, 4655. https://doi.org/10.1016/j.tifs.2018.02.019.

Neri, L., Faieta, M., Di Mattia, C., Sacchetti, G., Mastrocola, D., \& Pittia, P. (2020). Antioxidant activity in frozen plant foods: Effect of cryoprotectants, freezing process and frozen storage. Foods, 9(12), 1886. https://doi.org/10.3390/ foods9121886.

Nielsen, S. S. (2003). Food analysis laboratory manual, (Third ed., ). Ohio: Kluwer Academic/Plenum Publishers. https://doi.org/10.1007/978-1-4757-5250-2.

Nokthai, P., Lee, V. S., \& Shank, L. (2010). Molecular modeling of peroxidase and polyphenol oxidase: Substrate specificity and active site comparison. International Journal of Molecular Sciences, 11(9), 3266-3276. https://doi.org/1 0.3390/ijms11093266.

Nowak, K. W., Zielinska, M., \& Waszkielis, K. M. (2018). The effect of ultrasound and freezing/thawing treatment on the physical properties of blueberries. Food Science and Biotechnology, 28(3), 741-749. https://doi.org/10.1007/s10068-01 8-0528-5.

Perkins-Veazie, P., Collins, J. K., \& Clark, J. R. (1999). Shelf-life and quality of 'Navaho' and 'Shawnee' blackberry fruit stored under retail storage conditions. Journal of Food Quality, 22(5), 535-544. https://doi.org/10.1111/j.1 745-4557.1999.tb00184.x.

Phothiset, S., \& Charoenrein, S. (2013). Effects of freezing and thawing on texture, microstructure and cell wall composition changes in papaya tissues. Journal of the Science of Food and Agriculture, 94(2), 189-196. https://doi.org/10.1002/ jsfa.6226.

Piljac-Žegarac, J., \& Šamec, D. (2011). Antioxidant stability of small fruits in postharvest storage at room and refrigerator temperatures. Food Research International, 44(1), 345-350. https://doi.org/10.1016/j.foodres.2010.09.039.

Poiana, M.-A., Moigradean, D., Raba, D., \& Alda, L.-M. (2010). The effect of longterm frozen storage on the nutraceutical compounds, antioxidant properties and color indices of different kinds of berries. Journal of Food, Agriculture \& Environment, 8(1), 54-58.

Prior, R. L., Fan, E., Ji, H., Howell, A., Nio, C., Payne, M. J., \& Reed, J. (2010). Multilaboratory validation of a standard method for quantifying 
proanthocyanidins in cranberry powders. Journal of the Science of Food and Agriculture, 90(9), 1473-1478. https://doi.org/10.1002/jsfa.3966.

Rickman, J. C., Barrett, D. M., \& Bruhn, C. M. (2007). Nutritional comparison of fresh, frozen and canned fruits and vegetables. Part 1. Vitamins $C$ and $B$ and phenolic compounds. Journal of the Science of Food and Agriculture, 87(6), 930-944. https://doi.org/10.1002/jsfa.2825.

Sablani, S. S. (2015). Freezing of fruits and impact on anthocyanins. Processing and Impact on Active Components in Food, 18, 147-156. https://doi.org/10.101 6/B978-0-12-404699-3.00018-4.

Šamec, D., \& Piljac-Žegarac, J. (2011). Postharvest stability of antioxidant compounds in hawthorn and cornelian cherries at room and refrigerator temperatures-Comparison with blackberries, white and red grapes. Scientia Horticulturae, 131(1), 15-21. https://doi.org/10.1016/j.scienta.2011.09.021.

Šamec, D., \& Piljac-Žegarac, J. (2014). Fluctuations in the levels of antioxidant compounds and antioxidant capacity of ten small fruits during one year of frozen storage. International Journal of Food Properties, 18(1), 21-32. https:// doi.org/10.1080/10942912.2013.790423.

Siddiq, M., \& Dolan, K. D. (2017). Characterization of polyphenol oxidase from blueberry (Vaccinium corymbosum L.). Food Chemistry, 218, 216-220. https:/ doi.org/10.1016/j.foodchem.2016.09.061.

Singh, B., Suri, K., Shevkani, K., Kaur, A., Kaur, A., \& Singh, N. (2018). Enzymatic browning of fruit and vegetables: A review. Enzymes in Food Technology, 1, 63-78. https://doi.org/10.1007/978-981-13-1933-4_4.

Singleton, V. L., Orthofer, R., \& Lamuela-Raventós, R. M. (1999). Analysis of total phenols and other oxidation substrates and antioxidants by means of FolinCiocalteu reagent. Methods in Enzymology, 299, 152-178. https://doi.org/10.1 016/50076-6879(99)99017-1.

Skrede, G. (1996). Fruits, in: Freezing effects on Food Quality, Jeremiah, L. E. Ed., 183-246. New York: Marcel Dekker. https://doi.org/10.1201/9780203755495.

Taheri, R., Connolly, B. A., Brand, M. H., \& Bolling, B. W. (2013). Underutilized chokeberry (Aronia melanocarpa, Aronia arbutifolia, Aronia prunifolia) accessions are rich sources of anthocyanins, flavonoids, Hydroxycinnamic acids, and Proanthocyanidins. Journal of Agricultural and Food Chemistry, 61(36), 8581-8588. https://doi.org/10.1021/jf402449q.

Urbanyi, G., \& Horti, K. (1992). Changes in surface colour of the fruit and of the anthocyanin content of sour cherries during frozen storage. Acta alimentaria (Budapest), 21(3-4), 307-323.

Valdez, J. C., \& Bolling, B. W. (2019). Anthocyanins and intestinal barrier function: a review. Journal of Food Bioactives, 5, 18-30.

Wilkes, K., Howard, L. R., Brownmiller, C., \& Prior, R. L. (2014). Changes in chokeberry (Aronia melanocarpa L.) polyphenols during juice processing and storage. Journal of Agricultural and Food Chemistry, 62(18), 4018-4025. https:// doi.org/10.1021/jf404281n.

Wu, R., Frei, B., Kennedy, J. A., \& Zhao, Y. (2010). Effects of refrigerated storage and processing technologies on the bioactive compounds and antioxidant capacities of "Marion" and "Evergreen" blackberries. LWT - Food Science and Technology, 43(8), 1253-1264. https://doi.org/10.1016/j.lwt.2010.04.002.

Wu, X., Gu, L., Prior, R. L., \& McKay, S. (2004). Characterization of anthocyanins and proanthocyanidins in some cultivars of Ribes, Aronia, and Sambucus and their antioxidant capacity. Journal of Agricultural and Food Chemistry, 52(26), 7846-7856. https://doi.org/10.1021/jf0486850.

Yahia, E. M., Serrano, M., Valero, D., González-Aguilar, A., \& G. (2017). Influence of postharvest technologies and handling practices on phytochemicals in fruits and vegetables. Fruit and Vegetable Phytochemicals, 1, 609-628. https://doi. org/10.1002/9781119158042.ch27.

Yan, S., Li, L., He, L., Liang, L., \& Li, X. (2013). Maturity and cooling rate affects browning, polyphenol oxidase activity and gene expression of "Yali" pears during storage. Postharvest Biology and Technology, 85(1), 39-44. https://doi org/10.1016/j.postharvbio.2013.04.016.

Yuan, B., Danao, M. G. C., Lu, M., Weier, S. A., Stratton, J. E., \& Weller, C. L. (2018). High pressure processing (HPP) of aronia berry puree: Pilot scale processing and a shelf-life study. Innovative Food Science \& Emerging Technologies, 47, 241-248. https://doi.org/10.1016/j.ifset.2018.03.006.

Zhao, Y. (2007). Berry fruit : Value-added products for health promotion, (pp. 207223). Boca Raton Etc.: Crc Press/Taylor \& Francis, Cop. https://doi.org/10.1201/ 9781420006148.

\section{Publisher's Note}

Springer Nature remains neutral with regard to jurisdictional claims in published maps and institutional affiliations.

\section{Ready to submit your research? Choose BMC and benefit from}

- fast, convenient online submission

- thorough peer review by experienced researchers in your field

- rapid publication on acceptance

- support for research data, including large and complex data types

- gold Open Access which fosters wider collaboration and increased citations

- maximum visibility for your research: over $100 \mathrm{M}$ website views per year

At BMC, research is always in progress.

Learn more biomedcentral.com/submissions 